DE DE GRUYTER

OPEN

Polish Cartographical Review

Vol. 48, 2016, no. 3, pp. 129-140

DOI: $10.1515 /$ pcr-2016-0010

MIROSŁAW W. MEKSUŁA

Siedlce University of Natural Sciences and Humanities

mmex@vp.pl

LESZEK GRZECHNIK

Maria Curie-Skłodowska University, Lublin

leszek.grzechnik@poczta.umcs.lublin.pl

\title{
Concept of a landscape map according to Professor Franciszek Uhorczak
}

\begin{abstract}
In the article, the concept of landscape maps by Franciszek Uhorczak (1902-1981), Professor of the Maria Curie-Skłodowska University in Lublin, was discussed. The maps constitute a cartographic illustration of volume III, IV and V of "Universal Geography" edited by Państwowe Wydawnictwo Naukowe (the National Scientific Publishing House) (Warsaw 1965-1967) - the first Polish small-scale landscape maps of the world. From the perspective of the $50 \mathrm{~s}$, an attempt was undertaken to assess the editorial assumptions, landscape typology and selection of cartographic means used by the author, paying special attention to the selection of colours representing landscapes. Also, issues raising controversies related to the degree of generalization of particular elements of the content, typology of landscapes as well as map details were indicated. The performed analysis leads to the conclusion that landscape maps by Professor F. Uhorczak constituted one of the most significant achievements of Polish thematic cartography of the 20th century, and they are an unequaled model also for the contemporary cartographers.
\end{abstract}

Key words: landscape, landscape maps, colours on maps, cartographic generalization

\section{Introduction}

Landscape maps have a particular place among thematic maps. It results from the specific nature and complexity of the phenomenon such as 'landscape'. A very difficult editorial problem to solve is the necessity to present a synthetic image of relations between abiotic and biotic elements of the environment on the map - an image taking into account the significant impact of human activities on these relations. Authors of landscape maps must face the necessity to process a large amount of information concerning nearly all elements of the environment as well as numerous aspects of human activities. Based on them, they must perform regionalization and typology of landscapes and find an appropriate manner to present the results of their work on the map. Consequently, cartographic elaborations which significantly vary with the scale, the scope of content and the manner of defining landscapes are created (P. Krąż 2014).

The objective of the authors of this article was an attempt to analyze and assess the most valuable achievements of Polish cartography
- landscape maps elaborated by Professor Franciszek Uhorczak. It was achieved based on the analysis of the map content, source materials, available draft print-outs and unpublished reports of the associates of the Professor. The collected research material allowed a comparison with the contemporary achievements at the field of developing landscape maps. As a result of the performed analyses, it was possible to look at the work of F. Uhorczak critically through the eyes of a contemporary cartographer who has significantly more precise source data and fifty years of experience in the field of landscape research and edition of thematic maps.

Landscape maps are as old as the term 'landscape'. Landscape contents appeared on maps in ancient times, although maps were not explicitly called landscape maps. Due to their complex content, the earliest maps were landscape maps in large and medium scales, requiring collecting and analyzing a significantly smaller amount of data than in the case of developing small-scale maps presenting larger areas. Landscape maps by Professor Franciszek Uhorczak were among the first small-scale 
maps of the type in the world, and simultaneously the first ones in Poland (F. Uhorczak 1971).

The concept of presenting general geographical contents in the form of landscape maps of particular regions of the Earth was a result of broad geographical knowledge of F. Uhorczak and his rich experience in editing maps as well as (to some extent) a work of chance. By chance, due to a slow pace of developing illustrations for "Universal Geography" being prepared for printing by authors, The National Scientific Publishing House (PWN) entrusted F. Uhorczak with the entirety of works regarding the cartographic content in the form of colourful maps. Moreover, works on "Universal Geography" were conducted simultaneously with works on The World Atlas by PWN developed by the Polish Army Topographical Service. The atlas included general geographical maps with similar scales and territorial cover (F. Uhorczak 1971). Reluctance of the Professor to use the already existing elaborations and copy known solutions (both national and international) caused that he decided to prepare a completely new and original concept of maps - landscape maps.

Today, it is difficult to state with certainty what inspired F. Uhorczak to present general geographical content using this type of maps directly. The lack of information in literature on the subject and death of some cartographers cooperating with the Professor in the development of the above-mentioned maps prevent clear identification of the used sources of data concerning the environment. One can only assume with high probability that one of the most important inspirations could be Life Pictorial Atlas of the World by Rand McNally Publishing House from 1960. The atlas contained a series of maps of a landscape nature presenting particular parts of the world in a very visual manner; however, those maps were associated more with illustrations rather than with classic maps. The landform presented in perspective with applied, smoothly changing colors representing landscapes constituted the content of landscape maps. The Professor must have been familiar with this innovative landscape approach to present general geographical content and greatly impressed by it. The manner of presenting content on landscape maps in Life Pictorial Atlas of the World, although very attractive visually, significantly differed from the precise mathematical approach of F. Uhorczak to geography, and in particular cartography. Such an approach can be noticed, analyzing the content of Poland. General land use map (1956) or the first worksheets of World Settlement Map at the scale of $1: 1,000,000(1960,1964)$. Comparing the content of colorful landscape maps contained in "Universal Geography" with the content of Poland. General land use map, it is impossible to miss clear analogies, at least in the manner of presenting forests. This indicates clearly that these maps must have been created by the same cartographer.

\section{Concept assumptions}

Commencing the development of the cartographic content of "Universal Geography", Franciszek Uhorczak made several preliminary assumptions which consequently resulted in the author's original concept of maps contained in it. The first assumption was to avoid imitation and clear borrowings from other publishing houses of a similar nature. Secondly, maps were supposed to differ concerning their content (or at least form) from maps contained in The World Atlas prepared by PWN and the Polish Army Topographical Service. The third assumption concerned strict connections between the map content and the text of "Universal Geography" so that the cartographic illustration of particular volumes was as complete as possible (F. Uhorczak 1971).

Among 45 colourful cartographic tables in "Universal Geography", landscape maps constitute 19 in volume III (Europe without USSR), IV (USSR, Asia, Africa) and V (America, Australia and Oceania, Arctic and Antarctica, World Ocean). The fact that the landscape maps constitute more than $42 \%$ of all tables with colorful maps confirms the role of these maps in this publication.

Landscape maps by F. Uhorczak were developed in various scales. The areas of Europe (volume III) and the European part of USSR (volume IV) were presented the most precisely, at the 1:6,000,000 scale. The Mediterranean region including Southern Europe, the Central and Eastern part of North Africa as well as the Western part of the Middle East were presented at the $1: 12,000,000$ scale. Maps at the $1: 15,000,000$ scale definitely constitute the largest part of landscape maps (9 of 20). There are four maps of Asia, two maps of Africa, two 
maps of South America and one of North America (USA and Central America). This group is completed by a map of the Northern part of North America developed at a slightly smaller scale $(1: 18,000,000)$. The area of the entire USSR as well as Australia and Oceania were presented at the smallest scales $(1: 24,000,000)$, as well as maps of the polar regions - Antarctica and Arctic $(1: 30,000,000)$. Selection of scales resulted mainly from the necessity to adjust the map content to the content of particular chapters. Also, limited availability of source materials (especially cartographic) for some parts of the world was not without significance.

The most significant issue in developing the concept of landscape maps was to define the term 'landscape' and to conduct its classification and typology. In his publications, F. Uhorczak does not determine what 'landscape' is for him in a direct way nor he refers to its numerous definitions functioning at that time. The Professor bases his intuitive presentation of the landscape content on three leading factors characterizing altitude relations, climate and vegetation. The fundamental landscape elements presented with the least degree of generalization are forests. The details of their presentation can be best seen on maps at the largest scale $(1: 6,000,000)$ where in combination with agricultural areas (light yellow) spatial differentiation of forest landscapes and agricultural-forest landscape was presented very suggestively (fig. 1A). On the other maps at the $1: 15,000,000$ scale and smaller, the image of forests - although more generalized than in the case of the maps of Europe - is also a leading element of landscapes (1B). Other types of landscapes are presented at a much higher level of generalization (fig. 1C).

Presenting landscape differentiation of particular parts of the world, F. Uhorczak distinguished 83 landscapes. Furthermore, taking into account built-up areas, hydrographic elements (lakes, rivers, oceans) and polar areas covered with a tight ice cover, ice pack and ice floe, the number of categories reaches more than ninety (figs. 2 and 3). Nearly $76 \%$ of them are natural landscapes (8.5\% azonal, $10.5 \%$ areas of vertical zonation and $57 \%$ areas of horizontal zonation). The remaining $24 \%$ of categories are anthropogenic landscapes. The leading role of the above-mentioned forest landscapes is confirmed by a very large number of separations within this category - i.e. 23 , including forest-tundra, forest-steppe as well as Mediterranean forest landscapes and forest-steppe landscapes (fig. 2). Among the remaining types of landscapes most categories are observed in the case of various savannas $(9.5 \%)$, deserts $(8.5 \%)$, and semi-deserts and steppes (nearly $5 \%)$.

Analyzing the types of landscapes distinguished by Professor Uhorczak, it is easy to notice that apart from the most important landscape-creating factors - orography, climate and vegetation - a significant role was played by water relations (e.g. dry and wet pampa), open submerged and dry forests, etc., the nature of land cover (dune sands, sandy and stony deserts) and environmental physiognomy (e.g. open forests or high grass savannas). Anthropogenic landscapes are represented by significantly less categories (fig. 3). Although their number reaches 20 , in practice it should be limited only to four. They are agricultural landscapes, agricultural-forest (forest-agricultural) landscapes and forest-agricultural-steppe landscapes. The fourth type is basically one type - mosaic of agricultural landscapes and natural landscapes (forests, steppes, savannas or semi-deserts) within which there are agricultural areas (17 categories in total).

A very important element of the content of landscape maps is settlements (fig. 4). There are settlements with the number of population above 10 thousand (in China, India and Japan - 20 thousand, and in USSR due to a significantly smaller scale -50 thousand) presented using the signature method. In order to make it easier to read maps, names of larger towns were included. This principle concerns cities with population above 250 thousand on maps at $1: 6,000,000$ and $1: 12,000,000$ scales and above $0.5 \mathrm{mln}$ residents on maps in smaller scales. Excellent completion of information about the population distribution is the presentation of the main road connections in comparison to traditional railway connections (in the period when the discussed maps were created). It results from a close dependency between the network of road connections and the population distribution.

Presentation of altitudes (fig. 5) is not a less significant element of the landscape characteristics of particular regions of the world. Application of grey with the intensity of $15 \%$ and 
$30 \%$ printed on the maps allowed separation of two altitude zones in Europe, Africa and Australia: from 0 to $1,000 \mathrm{~m}$ above sea level and above $1,000 \mathrm{~m}$ above sea level, and three zones in Asia, America and USSR: from 0 to $1,000 \mathrm{~m}$ above sea level, from 1,000 to $4,000 \mathrm{~m}$
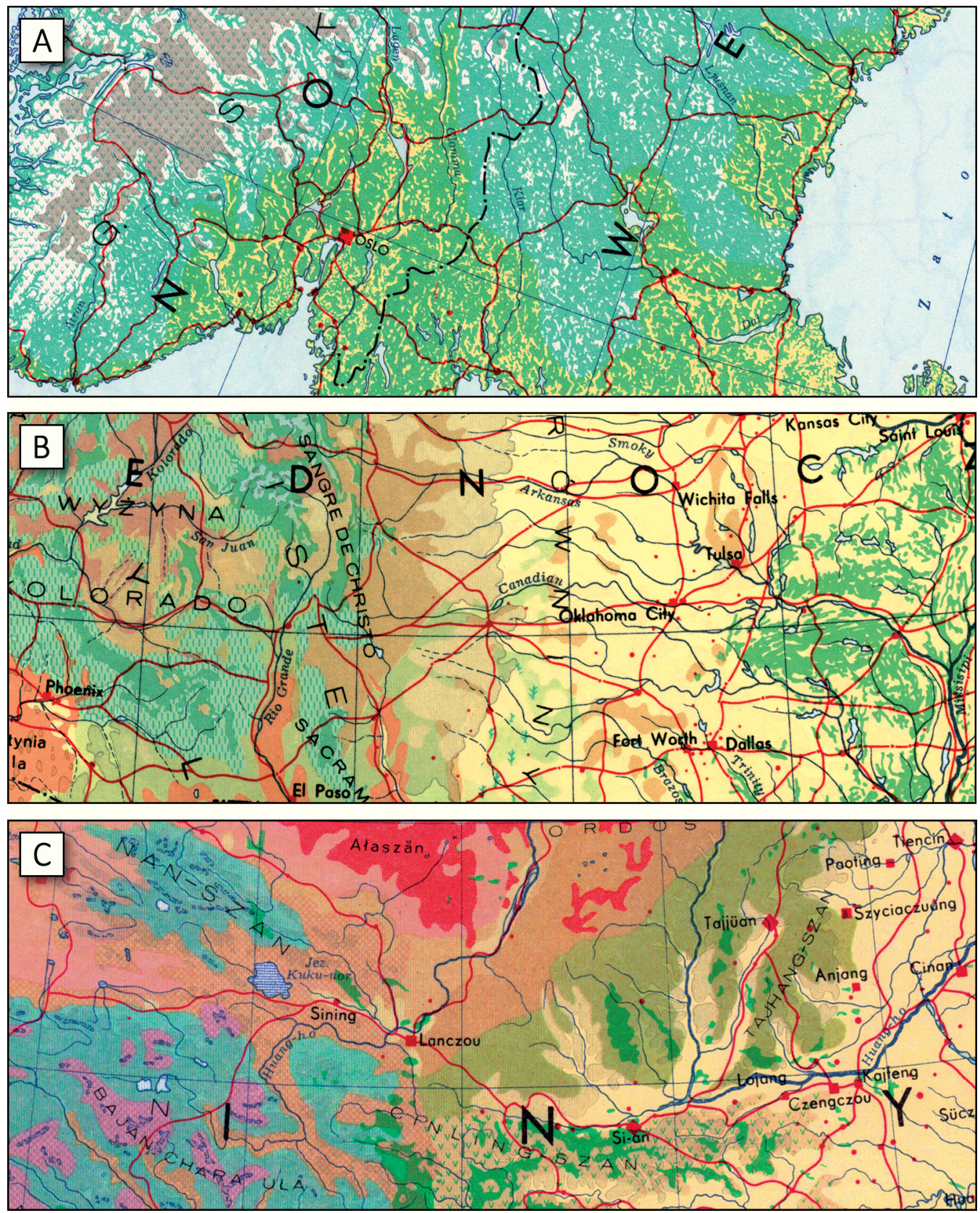

Fig. 1. Differences in generalization of the content of landscape maps included in "Universal Geography": A - a part of the map of Northern Europe V, scale 1:6,000,000 (volume III) , B - a part of the map of North America, scale 1:15,000,000 (volume V), C - a part of the map of Eastern Asia, scale 1:15,000,000 (volume IV) 


\section{Natural Iandscapes with horizontal zonality}

\begin{tabular}{|c|c|c|c|c|c|}
\hline & Arctic deserts & $=1=1=$ & Open paludal forests & & High grass savannas \\
\hline & Tundra & & $\begin{array}{l}\text { Open submerged } \\
\text { forests }\end{array}$ & & Grass savannas \\
\hline & Forested tundra & & Open dry forests & & Low grass savannas \\
\hline & Forested steppe & & Tropical spine forests & & Scrub savannas \\
\hline$a^{0} a^{2}$ & Grassy scrubland & & Open forests & $\psi^{*} *$ & Scrub spine savannas \\
\hline & Temperate zone forests & & Open spine forests & & Desret savannas \\
\hline & Equatorial rain forests & & Spine forests and scrub & & Temperate semideserts \\
\hline & $\begin{array}{l}\text { Equatorial rain } \\
\text { submerged forests }\end{array}$ & & Forested steppes & & Subtropical semideserts \\
\hline & Equatorial park forests & & Woody-Mediterranean & & $\begin{array}{l}\text { Subtropical scrub } \\
\text { semideserts }\end{array}$ \\
\hline & Gallery forests & & Mediterranean & & $\begin{array}{l}\text { Subtropical grass-scrub } \\
\text { semideserts }\end{array}$ \\
\hline & Mangrove forests & & Typical steppes & & Temperate sandy deserts \\
\hline & Park forests & & Desret steppes & & Tropical sandy deserts \\
\hline & Open forests & & Desret scrub steppes & & Sandy deserts \\
\hline & Tropical rain forests & & Dry pampa & $\nabla$ & Stony deserts \\
\hline & Open tropical dry forests & & Wet pampa & & $\begin{array}{l}\text { Stony deserts } \\
\text { and semideserts }\end{array}$ \\
\hline & Subtropical open forests & & Park savannas & & \\
\hline
\end{tabular}

Fig. 2. List of cartographic patterns used by F. Uhorczak to present natural landscapes with horizontal zonation (the authors' elaboration) 


\section{Natural azonal and other landscapes}
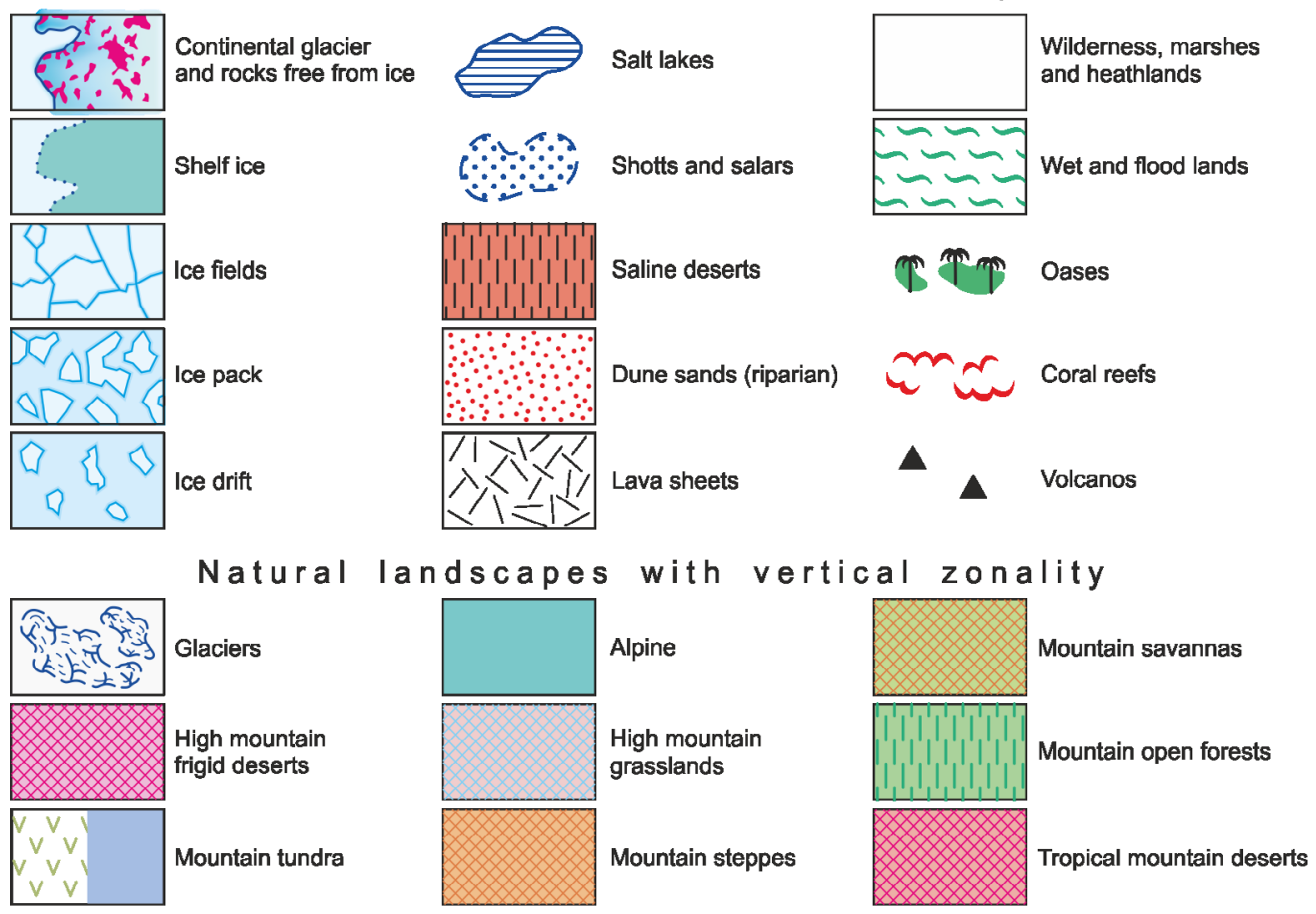

Anthropogenic Iandscapes

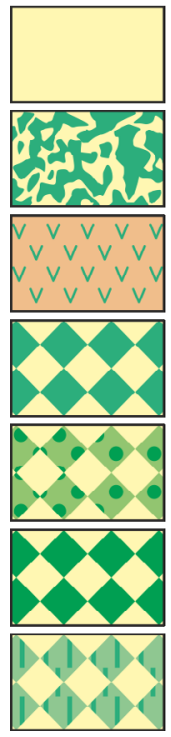

Agricultural

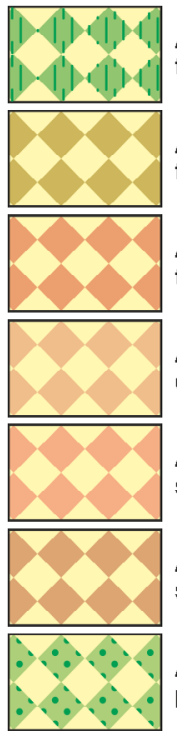

Agricultural within tropical open forests

Agricultural - forestry (forestry - agricultural)

Agricultural within forested steppes

Agricultural - forestry - steppe (reiterated)

Agricultural within typical steppes

Agricultural within temperate forests

Agricultural within equatorial park forests

Agricultural within equatorial rain forests

Agricultural within open forests

Agricultural within desert steppes

Agricultural within steppes of dry pampa

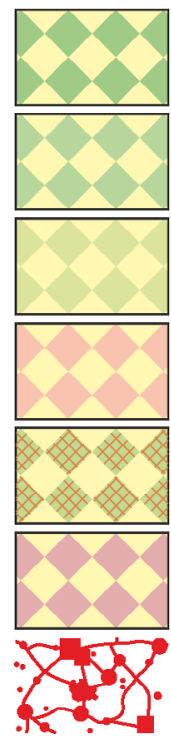

Agricultural within high grass savannas

Agricultural within low grass savannas

Agricultural within scrub savannas

Agricultural within desert savannas

Agricultural within mountain savannas

Agricultural within steppes of wet pampa

Agricultural within temperate semideserts

Agricultural within park savannas

Towns and more important road connections

Fig. 3. List of cartographic symbols and paterns used by F. Uhorczak to present natural landscapes with vertical zonation, anthropogenic, azonal and others (the authors' elaboration) 
above sea level and above 4,000 $\mathrm{m}$ above sea level. Combining this with the various mountain landscapes (e.g. mountain tundra, alpine landscape, alpine meadows, etc.) allowed relations between landscape zones and topography of the Earth to be presented.

The image of landscape diversity is completed with a hydrographic network represented by larger rivers and important channels as well as sweet and salty water lakes. On the maps, also large mountain glaciers, continental glaciers ice sheets, ice shelves and areas where sea ice is present as well as ice-free rocks on the areas of land in the polar zones and distribution of coral reefs in the tropics were marked.

\section{Colours of landscape maps}

In terms of graphics, landscape maps in "Universal Geography" are characterized by original and very careful selection of colours allowing suggestive and consistent representation of landscapes. To enable correct representation of similarities and differences between particular landscapes, the selection of colours was subject to several principles. An increase of the degree of dryness was highlighted by an increase in intensity of warm colours - from pink and orange to bright red (fig. 6A), while an increase in humidity in the landscapes of the tropics with an increase in intensity of green (fig. 6B). To highlight mountain landscapes, a brown, purple and blue grid pattern was applied (fig. 6C). To present a decrease in temperature between cool and cold landscapes, the scale of blue and green, through light purple to purple was used (fig. 6D). In order to distinguish between semi-deserts and deserts of the temperate and subtropical zones cooler and warmer shades of colours were used (fig. 6E), while to mark steppes - various shades of brown were used (fig. 6F). To highlight anthropogenic elements with the greatest impact on landscapes (settlement sand communication network) red was applied (fig. 4).

The effect of applying the above-mentioned principles was a colorful image of landscape diversity allowing profound and visual repre-

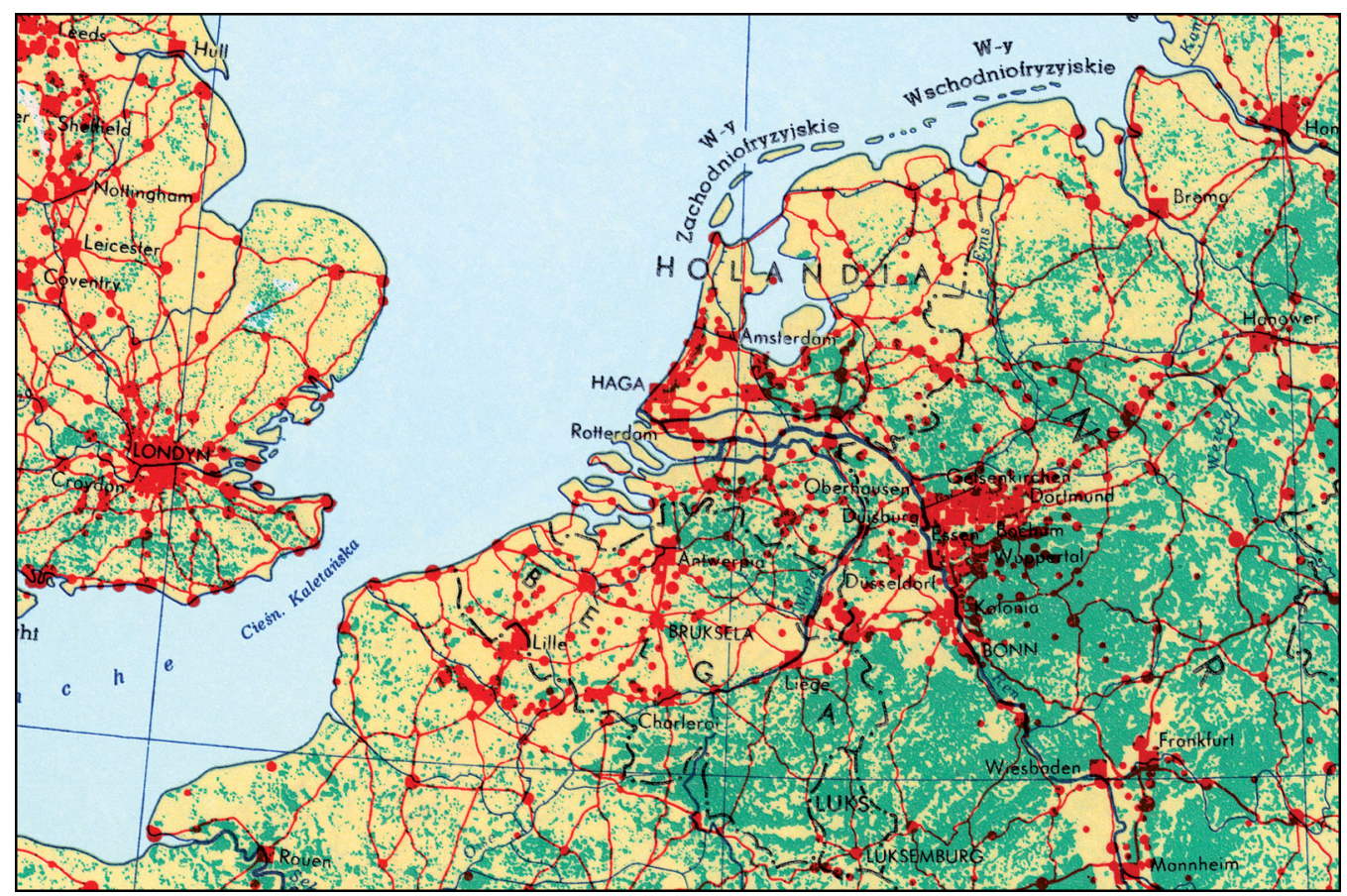

Fig. 4. Settlement states and road network on the landscape map by F. Uhorczak (a part of the map of Western Europe, scale 1:6,000,000 from volume III of "Universal Geography") 


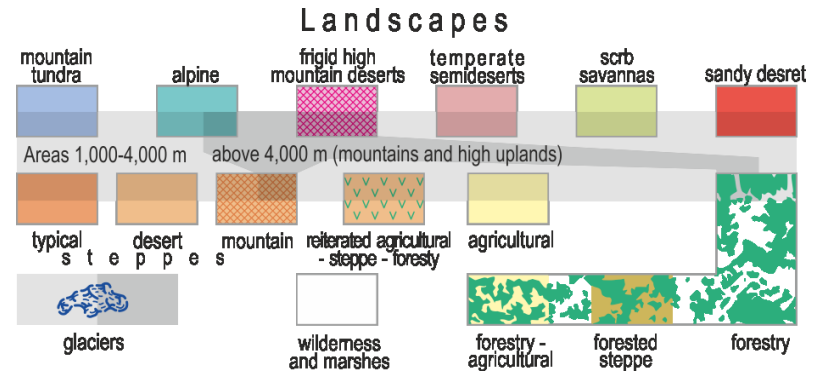

Fig. 5. An example of a legend of landscape maps by F. Uhorczak with marked altitude zones (the authors' elaboration based on the map of South-East Asia from volume V of "Universal Geography")

sentation of the complexity of dependencies between various components of the environment. It also became possible by printing the maps in 14 colours (F. Uhorczak 1967).

Soon after "Universal Geography" was published, it turned out that the image of landscape diversity achieved by F. Uhorczak through his intuitive selection of colours has one more unexpected advantage. The analysis of the first images of the surface of the Earth published by NASA, made from the Earth orbit, indicated a high degree of correlations between the variability of colours in the satellite images and the landscape maps by Professor Uhorczak (A. Ciołkosz, J. Miszalski 1969). This correlation - although incomplete - (due to e.g. seasonal changes in colours of the surface of the Earth) caused that the cognitive qualities of landscape maps developed according to the concept of Professor Uhorczak are appreciated even more.

\section{Controversies}

Despite numerous undeniable advantages of the landscape maps by Professor Uhorczak, they were not free from defects. It results mostly from their pioneer nature. A very small number of small-scale landscape maps and the lack of experience in developing such maps significantly impeded concept works. Moreover, editing landscape maps created the necessity to collect a great amount of source data, mainly in the form of cartographic and statistical materials, referring to all continents. Collection of accurate, reliable, and most of all comparable data concerning topography of the Earth, climate, vegetation, communication and settlement constituted an exceptionally difficult task. Most cartographic sources were physical maps containing hypsometry, hydrography and settlement as well as important communication connections. Small-scale maps providing information about land cover - very important in the development of landscape maps - were very rare. On such maps forests were most frequently presented. Most probably, this fact constituted the reason why Professor F. Uhorczak made forests the most exposed and the least generalized element of the content of his maps, which consequently contributed to the diversity of the degree of generalization of particular types of landscapes. Today, it is very difficult to assess whether and to what extent it was a deliberate effect and to what extent it resulted from the lack of proper quality data.

Certain reservations are also raised by incompleteness of landscape typology made by F. Uhorczak. An example can be the lack of separation of taiga or division of forests into deciduous, coniferous and mixed as well as evergreen and seasonal (loosing leaves in the cold or dry season). Similar doubts are also raised by differentiation of steppes from pampa (South America) and the lack of prairie (North America).

The approach of F. Uhorczak to anthropogenic landscapes also seems to be a debatable issue. Typology of some anthropogenic landscapes was excessively developed, e.g. agricultural landscapes within forests or steppes (nearly 20 categories in total), while others rather significant were omitted: division between intensive and extensive farming, agricultural irrigated lands or lands with a strong concentration of 

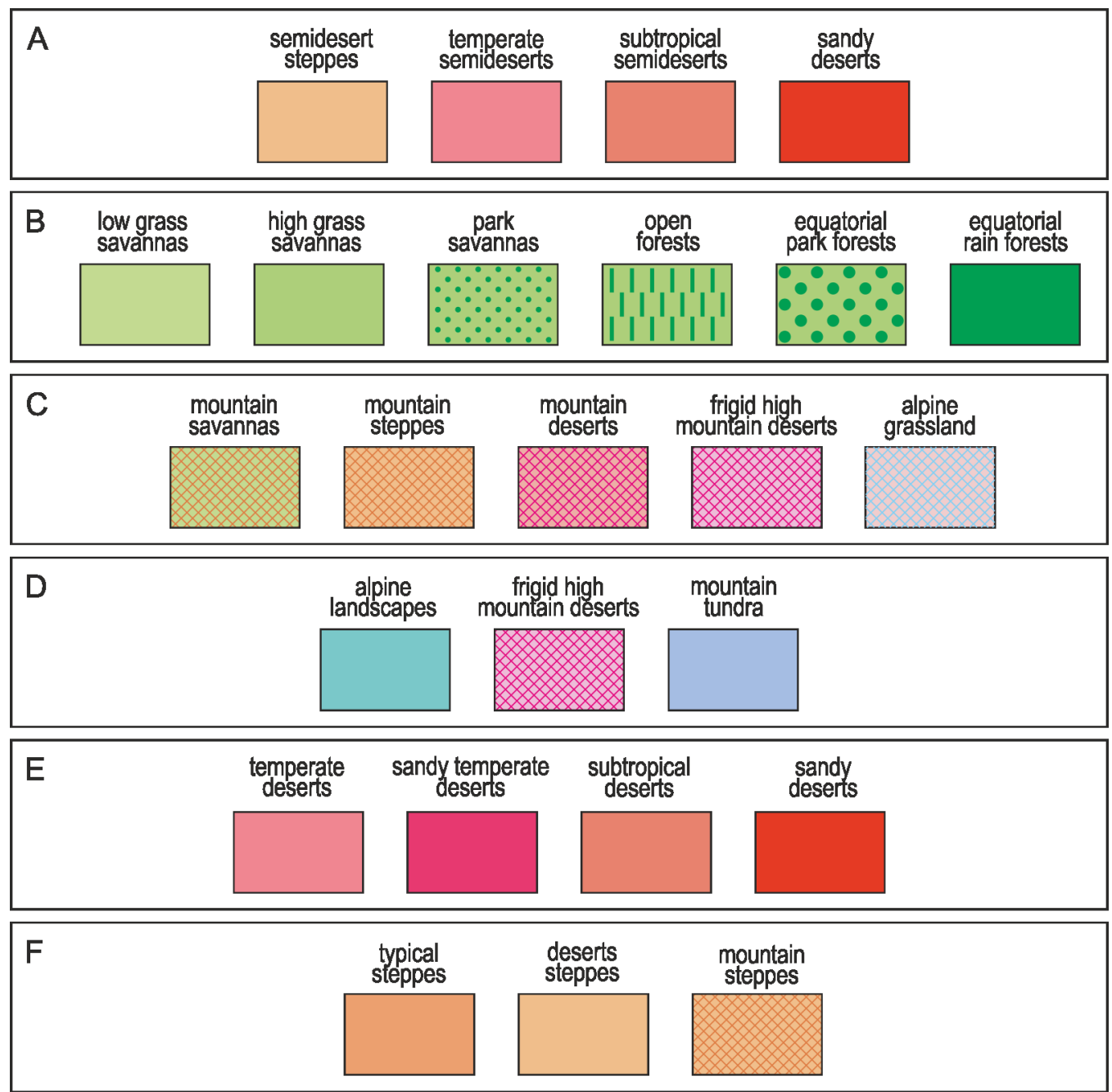

Fig. 6. Examples of the application of colour patterns by F. Uhorczak to show dependencies between landscapes - explanation in the text (the authors' elaboration)

industry (e.g. Ruhr, Upper Silesia). However, it must be stated that despite fifty years since the publication of the landscape maps by Professor Uhorczak, the issue of clear definition of the term 'landscape' and implementation of regionalization and landscape typology without any reservations is still actual and far from being solved (U. Myga-Piątek 2001, T.J. Chmielewski 2008, P. Krąż 2014).

One may also have doubts concerning the reach of some landscapes. An example is the image of agricultural landscapes in the central part of Africa. Comparing the landscape map by Professor Uhorczak (fig. 7B) with contemporary elaborations concerning agriculture in Africa (fig. 7A), we can see that in some regions (e.g. the Central African Republic) occurrence of agricultural landscapes was clearly overestimated. Despite a nearly four-fold increase in the number of population within the last half-century of which more than $80 \%$ work in agriculture, the contemporary area of land used for 
agriculture is significantly smaller than presented on the landscape map in "Universal Geography". However, such cases on the maps by
F. Uhorczak are few. Most likely, they result from the low detail of source materials used by the author.
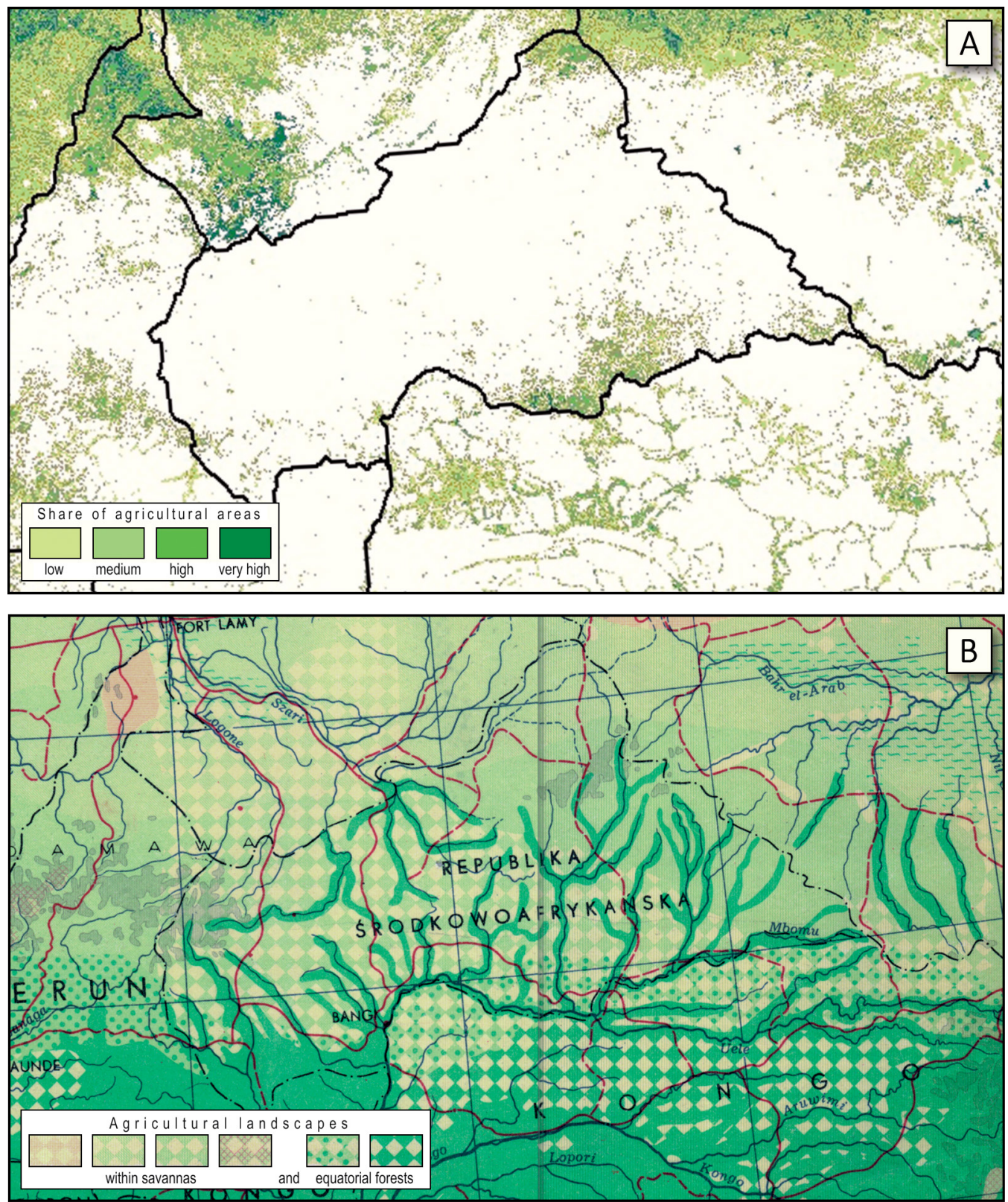

Fig. 7. Agricultural areas in Central Africa: A - on the map developed based on contemporary satellite data (the author's elaboration based on https://earthzine.org/wp-content/uploads/2012/01/africa.jpg);

B - on the map by F. Uhorczak (a part of the map of Northern Africa, scale 1:15,000,000 from volume IV of "Universal Geography"). 


\section{Summary}

The presentation of particular regions of the Earth on colourful landscape maps turned out to be a much more effective manner to present general geographical content than the traditional hypsometric map used for this purpose. Beauty, simplicity and the innovative manner of approaching the content caused that the landscape maps by Professor F. Uhorczak quickly gained worldwide fame and they were included among the most outstanding achievements of Polish cartography (J. Mościbroda 1984; M. Sirko, J. Mościbroda 2002). Also, there have been suggestions to edit those maps and publish them in the form of review maps and wall continent maps. Despite actions undertaken to implement this purpose and the development of original landscape maps of North America, South America and Africa, the project has not been implemented.

The effective and visual content presentation which characterized the first landscape maps made them evolve quickly and replace traditional physical maps in atlases. An additional facilitation was the fact that since the turn of the sixties and seventies of the 20th century, cartographers obtained access to satellite images and pictures. Since then, information of the global range - previously difficult or impossible to obtain - has been commonly used to develop landscape maps. It caused that small-scale landscape maps became a standard

\section{Literature}

Chmielewski T. J., 2008. Zmierzając ku ogólnej teorii systemów krajobrazowych. „Problemy Ekologii Krajobrazu”, T. 21, pp. 93-110.

Ciołkosz A., Miszalski J, 1969, Barwy na mapach krajobrazowych a barwy Ziemi na zdjęciach satelitarnych. „Polski Przegląd Kartograficzny” T. 1, nr 4, pp. 13-17.

Czerny A., 1983, Mapy krajobrazowe w atlasach świata. „Polski Przegląd Kartograficzny” T. 15, nr 4, pp. 167-174.

„Geografia Powszechna” Tom III - Europa (bez ZSRR). 1965, Ed. A. Wrzosek, Warszawa: Państwowe Wydawnictwo Naukowe.

„Geografia Powszechna” Tom IV - Związek Socjalistycznych Republik Radzieckich, Azja, Afryka. 1967, Ed. A. Zierhoffer, Warszawa: Państwowe Wydawnictwo Naukowe. type of cartographic presentations (A. Czerny 1983).

The above-mentioned imperfections of landscape maps developed by Professor Franciszek Uhorczak cannot overshadow their undeniable advantages. Both the innovative concept and the level of editorial development, simplicity, visuality and aesthetical values cause that the maps must be included among exceptional achievements of both Polish and world cartography. It can be stated that the maps set the course for future cartographic landscape elaborations.

Going through the contemporary geographic atlases, especially those developed for educational purposes, it is easy to find numerous examples of landscape maps. Even though the diversity of solutions applied to develop them is great, and particular maps often vary significantly, on each of them one can notice traces of the first small-scale landscape maps developed by F. Uhorczak. Even though more than fifty years passed since their publication, and despite years of significant progress in the field of environmental studies, remote sensing, computing and printing as well as the development of numerous disciplines involved in the studies of landscapes, the maps by Professor Franciszek Uhorczak still constitute an excellent example of cartography and an unsurpassed model for numerous contemporary cartographers.
„Geografia Powszechna” Tom V - Arktyka, Ameryka, Australia i Oceania, Antarktyda, Ocean Światowy. 1967, Ed. A. Jahn, Warszawa: Państwowe Wydawnictwo Naukowe.

Krąż P., 2014, Mapy krajobrazowe - wybrane problemy ich tworzenia $i$ zastosowania. „Współczesne problemy i kierunki badawcze w geografii" T. 2, pp. 63-76. Kraków: Instytut Geografii i Gospodarki Przestrzennej Uniwersytetu Jagiellońskiego.

Mościbroda J., 1984, Najistotniejsze cechy działalności naukowej. W: W kręgu Romerydów - Profesor Franciszek Uhorczak, Lublin: Uniwersytet Marii Curie-Skłodowskiej, Instytut Nauk o Ziemi, Zakład Kartografii, pp. 17-24.

Myga-Piątek U., 2001, Spór o pojęcie krajobrazu w geografii $i$ dziedzinach pokrewnych. „Przegląd Geograficzny" T. 73, z. 1-2, pp. 163-176. 
Sirko M., Mościbroda J., 2002, Prof. dr Franciszek Uhorczak - Jego wkład w rozwój polskiej kartografii (w stulecie urodzin) „Polski Przegląd Kartograficzny" T. 34, nr 4, pp. 251-260.

Uhorczak F., 1967, Mapy barwne w Geografii Powszechnej. W: „Geografia Powszechna” Tom V Arktyka, Ameryka, Australia i Oceania, Antarktyda, Ocean Światowy. Warszawa: Państwowe Wydawnictwo Naukowe, pp. 416-417.

Uhorczak F., 1969, Polska Przeglądowa Mapa Użytkowania Ziemi 1:1 000 000, A. Część tekstowa. „Prace Geograficzne” Nr 17. Warszawa: Instytut Geografii Polskiej Akademii Nauk.

Uhorczak F., 1971, Mapy barwne w Geografii Powszechnej PWN - w szczególności mapy krajobrazowe. "Materiały Ogólnopolskich Konferencji Kartograficznych" Tom 1. - Problemy kartografii tematycznej, Warszawa-Lublin: Polskie Towarzystwo Geograficzne - Komisja Kartograficzna, Państwowe Przedsiębiorstwo Wydawnictw Kartograficznych, pp. 192-219.

\section{Maps}

Mapa Osadnictwa Świata - World Settlement Map 1:1 000 000. NM-34 Kraków. Lublin: Zakład Geografii Ekonomicznej, Uniwersytet Marii Curie-Skłodowskiej, 1960.

Mapa Osadnictwa Świata - World Settlement Map 1:1 000 000. NL-32 Milano. Lublin: Zakład Geografii Ekonomicznej, Uniwersytet Marii Curie-Skłodowskiej, 1964.

Mapa Osadnictwa Świata - World Settlement Map 1:1 000 000. NL-33 Trieste. Lublin: Zakład Geografii Ekonomicznej, Uniwersytet Marii Curie-Skłodowskiej, 1964.

Polska. Przeglądowa mapa użytkowania ziemi 1:1000 000. Warszawa: Główny Urząd Geodezji i Kartografii, Państwowe Przedsiębiorstwo Wydawnictw Kartograficznych, 1956.

https://earthzine.org/wp-content/uploads/2012/01/ africa.jpg 